\title{
POWER QUALITY MEASUREMENTS IN A STEEL INDUSTRY WITH ELECTRIC ARC FURNACES.
}

\author{
Pedro E. Issouribehere, Juan C. Barbero, Fernando Issouribehere, IEEE Member, and Gustavo A. Barbera
}

\begin{abstract}
Many loads connected to electric power systems can cause power quality problems at all voltage levels and for very different power ratings due to their unbalanced and non-linear behavior characteristics.

This paper describes the aspects of power quality at the point of common coupling (PCC) where an arc furnace for steel melting with alternating current is connected. By measurements of Flicker, harmonics content in voltage and current, active and reactive power and power factor, the preservation of the reference levels for the supply voltage and emission limits for the furnace as a customer are evaluated.

The evaluation of power quality of contemporary International and Argentinian standards is given.

The different phases in the operation of the arc furnace are described in detail and illustrated with measurements.
\end{abstract}

Index Terms - Arc Furnaces. Flicker. Harmonics. Power Quality. STATCOM. SVC.

\section{INTRODUCTION}

$\mathrm{I}$ $\mathrm{n}$ order to ensure the electromagnetic compatibility in distribution networks, the perturbation levels in different points of them must be confined to certain limits [1] and [2], process that involves a permanent control of emissions due to every disturbing load connected to the network.

Electric arc furnaces loads can result in serious electrical disturbances on a power system. Low level amplitude modulation of the supply voltage of less than $0.5 \%$ can cause annoying Flicker in lamps and invoke public complaints when the frequencies lie in the range of $3-10 \mathrm{~Hz}$.

An electric arc furnace of $75 \mathrm{MW}$ for steel melting was connected at $132 \mathrm{kV}$ voltage level in the Transmission System of Buenos Aires (Argentina). A second electric arc furnace of the same power rating will be connected in the future. The IITREE has made measurements of some power quality indicators to check the reference levels at the Point of Common Coupling (PCC) and the emission levels of the arc furnace as a disturbing load. The quantities measured are voltage and current harmonics, Flicker, power factor and active and reactive power.

According to the electrical parameter data, a single phase electric circuit of the arc furnace was obtained. The measurements made during the several phases in the operation of the arc furnace support the validity of the model.

Technical solutions for the Flicker problem are presented.

(*) P. Issouribehere, J. Barbero, F. Issouribehere, and G. Barbera are with IITREE-LAT. Facultad de Ingeniería Universidad Nacional de La Plata. (1900) 48 y 116. La Plata. Argentina (e-mail: iitree@iitree-unlp.org.ar).

\section{DESCRIPTION OF THE POWER SYSTEM AND PCC}

The one-line diagram of the power system and the steelwork is shown in Fig. 1.

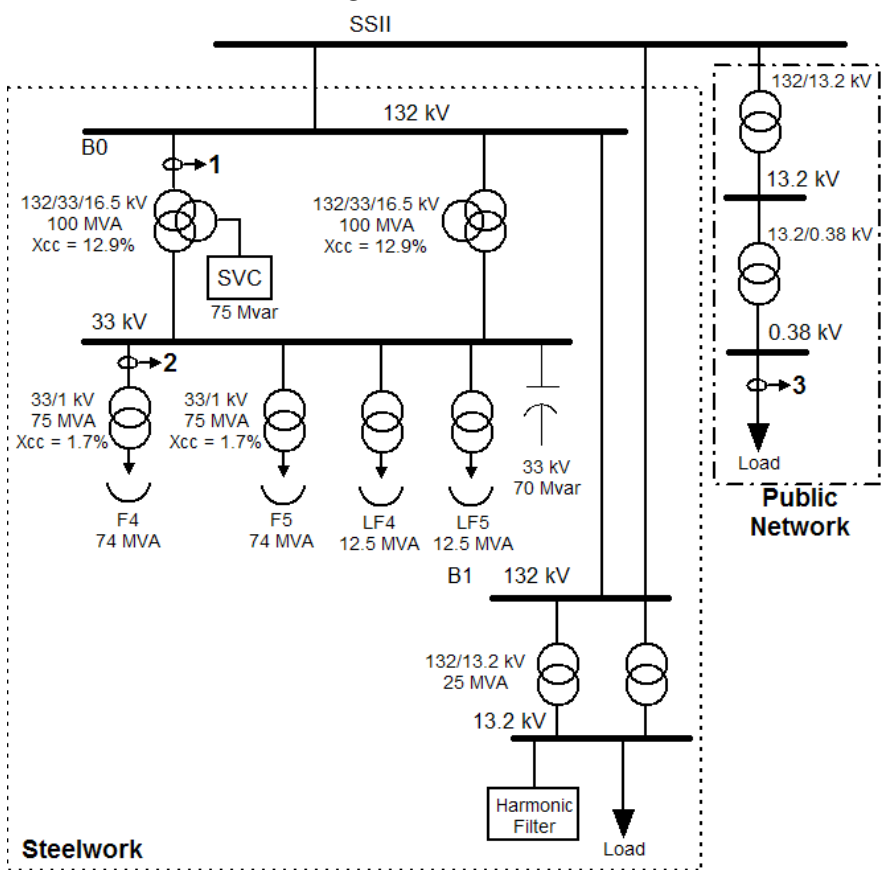

Fig. 1: Electrical system configuration.

As it is shown in Fig. 1, the steelwork is supplied directly from public transmission network at $132 \mathrm{kV}$. Power quality measurements were made at $132 \mathrm{kV}$ (point 1) and in the measuring transformers on the primary side of the arc furnace transformer (point 2). Flicker measurements at low voltage levels of public network (point 3 ) were also performed.

\section{Characteristics of Electric ArC furnaces}

An electric arc furnace consists of a refractory lined shell which holds the charge, usually scrap metal. Three large electrodes, usually of graphite, are held in special clamps on a swing support structure which can be swung aside for charging, and which allows each electrode to be raised or lowered according to the output of the control system.

After the furnace is charged with scrap, operation begins by lowering the electrodes to strike electric arcs between the electrodes and the scrap. The heat generated by the three electric arcs provides the energy required to melt the scrap. There are several phases in the operation of the arc furnace, each presenting a different impact on the power system in terms of Flicker, namely the: 